\title{
Carcass and fur yield, internal organ characteristics and GIT morphometry of rabbits fed diets containing composite mango (Mangifera indica) fruit reject meal
}

\begin{abstract}
The experiment was carried to determine the effect of mango fruit reject meal on carcass and fur yield, internal organ characteristics and GIT morphometry of rabbits. Mango fruit rejects were sliced; peel and flesh/pulp together and the seed discarded, sun dried to $<10 \%$ moisture and milled to obtain mango fruit reject meal (MFRM). The MFRM was sub-sampled and its proximate composition determined. After which, it was included at $0,5,10,15$ and $20 \%$ respectively. Twenty weaned rabbits of mixed sex and breed were fed the diets for 70days and carcass, fur, internal organs and GIT were evaluated on the 70thday. Apart from fasted weight (1475.00-1758.33g) and head relative weight $(6.45-7.89 \%)$ which were significantly different $(\mathrm{P}<0.05)$; the former being higher and the latter lower at 20\%MFRM, the rest of the carcass parameters measured were not significantly affected $(\mathrm{P}>0.05)$. Fur yield (7.71$11.52 \%)$ was significantly lower $(\mathrm{P}<0.05)$ at control $(0 \% \mathrm{MFRM})$. Internal organs were not significantly affected $(\mathrm{P}>0.05)$. Caeca relative length varied without pattern, being the only parameter among GIT components affected significantly. It was concluded that $20 \%$ MFRM replacement of maize by MFRM was safe and optimum for rabbit meat production and necessary for better fur yield. It was suggested that higher levels should be investigated to determine the optimum level of MFRM in rabbit diets to maximize meat, fur yield and profit.
\end{abstract}

Keywords: rabbit carcass, internal organs, fur, mango fruit reject
Volume 5 Issue $3-2017$

\author{
Orayaga KT,Akau KJ, Dafam JJ, Odeh LO \\ Department of Animal Nutrition, University of Agriculture, \\ Nigeria
}

\section{Correspondence: Orayaga KT, Department of Animal Nutrition, University of Agriculture, PMB 2372 Makurdi, Benue state, Nigeria, Tel +234-(0)8I50943 I22,}

Email orayacollins@gmail.com

Received: September 18, 2017 | Published: December 06,
Abbreviations: MFRM, mango fruit reject meal; GIT, gastrointestinal tract; SEM, standard error of mean; LS, level of significance; NS, no significant difference; S, significant

\section{Introduction}

Although there is continuous search for non-conventional feedstuffs which are more affordable and available in place of costly conventional feedstuffs by animal nutritionists because it is one way that could provide animal protein for a greater population of the world, ${ }^{1}$ the final destination has not been reached. This is because the feed value of non-conventional feedstuffs is low in most cases. ${ }^{1-3}$ More so, the fact that feeding accounts for about $70 \%$ of the cost of producing non-ruminants animals (poultry especially) is no news any longer among animal producers. This cost varies among animal species. Even among non-ruminant animal species, feeding cost differs depending on the management system adopted and the animal species involved since feed cost in rabbit as low as $26.57 \%$ of total $\operatorname{cost}^{4,5}$ have been reported. Evaluations on growth performance or digestibility alone do not tell enough since the measured weight may not be the needed components of the carcass. Growth performance of rabbits was similar in an experiment, 4,5 but when the same procedure was followed and carcass evaluated, significant differences occurred for. ${ }^{6}$

Rabbit as an alternative animal protein source capable of bridging the gap in animal protein consumption among people in developing and developed countries of the world, due to its low cost of production occasion by higher feed conversion ratio from cheaper feedstuffs, higher prolificacy and short generation intervals. ${ }^{7}$ Rabbits are herbivores and have the ability to degrade substantial amount of fibre. ${ }^{8}$ The use of forages such as Moringa oleifera, ${ }^{9}$ Acacia (Acacia nilotica $)^{7}$ and Leptadenia Hastata ${ }^{10}$ as feedstuff in rabbit diets have been reported. Fruit by-products such as Mango (Mangifera indica) seed kernel ${ }^{11}$ and mango fruit reject ${ }^{12}$ have also been used as feedstuff for rabbits. Mango (Mangifera indica) fruit is nutritionally rich and has good flavor, aroma, taste, and health promoting characteristics. ${ }^{13}$ It is produced on a large scale around many countries of the world, with total world figure put at 39 million metric tons.${ }^{14}$ Nigeria occupies the $9^{\text {th }}$ position on the list of top-most producers of mango around the world, with a production figure of 850000 metric tons. ${ }^{13}$

Though the fruit is good it becomes unfit for human consumption because of infections, bruises, improper handling, and activities of animals (especially birds) on the fruit, and therefore rejected. ${ }^{1}$ For the local mango, a whole tree stand may be rejected and allowed to be wasted by children or birds due to relatively poorer taste. These rejected fruits, known as cull fruits litter the ground during its season, there by constituting environmental hazard. ${ }^{14}$

Little has been done to convert rejected mango fruit pulp into useful products such as animal feed. However, considering the high energy value of mango fruits, ${ }^{13}$ these rejected fruits could serve as a feed resource in animal feeding, mainly as a source of energy because of its high energy of $3533.57 \mathrm{kcal} / \mathrm{kg} \mathrm{DM} .{ }^{16}$ The seed and peel of mango fruits have been used as animal feedstuffs. According to report ${ }^{17}$ dried mango peels included in finishing pig diets at $10 \%$ had no deleterious effect on feed conversion ratio, animal performance and economics 
of production. MFRM have been include in broiler diets at $10-12 \%$ as safe levels ${ }^{2}$ and $20 \%$ in rabbit diets was comparable to control with respect to growth performance as well as digestibility and superior to control (maize based diets) on economics of production. ${ }^{12}$

The use of MFRM will reduce pressure on maize and at the same time check environmental hazards they create. Mango fruit is reported to be palatable and used as a spice in many food formulas for human consumption. Orayaga et al. ${ }^{12}$ reported that rabbits may have equally appreciated the flavor in MFRM, counting the test diets more palatable and consuming the test diets more (quantitatively) than the control; accordingly, the effect of more consumption, similar feed conversion ratio and digestibility produced higher final weight of rabbits, though not significant $(\mathrm{P}>0.05)$, resulting to significantly better $(\mathrm{P}<0.05)$ economics of production on diet containing 20\% MFRM.

Carcass composition, internal organs and gastro-intestinal tract (GIT) morphometry are affected by the quality of diets animals are exposed to. ${ }^{6,18}$ The experiment was therefore carried to determine the effect of mango fruit reject meal on carcass and fur yield, internal organ characteristics and GIT morphometry of rabbits

\section{Materials and methods}

\section{Experimental site}

The experiment was conducted at the Rabbit Section of the

Table I Composition of rabbit experimental diets containing MFRM
Livestock Unit, on the Teaching and Research Farm, University of Agriculture Makurdi, Benue State, Nigeria. The area is warm with a minimum temperature range of $24.20 \pm 1.40^{\circ} \mathrm{C}$ and a maximum temperature range of $36.33 \pm 3.70^{\circ} \mathrm{C} . .^{19}$

\section{Preparation of mango fruit reject and diets}

The mango fruit rejects (test ingredient) were collected together as a composite irrespective of variety from mango tree stands and fruit markets' refuse sites around Makurdi town and its surroundings during mango fruit season, which is between March and May. The composite half-ripe mango fruits which comprised mainly of Alphonso, Julie, Hindi, Peter, local mango and John varieties were cleaned, sliced to a thickness of $1-3 \mathrm{~mm}$ such that peel and pulp were together. The seeds were discarded and the slices sun dried by spreading them out on polyethylene sheet, placed directly under the sun for seven (7) days, when the material was dried less than $10 \%$ moisture and stored in polyethylene sacks until it was used. Before the composite mango fruit reject was incorporated into the diets, it was milled using corn milling machine to obtain mango fruit reject meal (MFRM). Mango fruit reject meal was then sub-sampled and the proximate composition determined following standard procedure ${ }^{20}$ before it was incorporated in rabbit diets at $0,5,10,15$ and $20 \%$ to produce $0 \%$ MFRM (control), 5\%MFRM, 10\%MFRM, 15\%MFRM and 20\%MFRM diets presented in Table 1.

\begin{tabular}{|c|c|c|c|c|c|}
\hline \multirow{3}{*}{ Ingredient \% } & \multicolumn{5}{|c|}{ Experimental diets } \\
\hline & $0 \%$ & $5 \%$ & $10 \%$ & $15 \%$ & $20 \%$ \\
\hline & MFRM & MFRM & MFRM & MFRM & MFRM \\
\hline Maize & 40.00 & 35.00 & 30.00 & 25.00 & 20.00 \\
\hline MFRM & 0 & 5.00 & 10.00 & 15.00 & 20.00 \\
\hline Soyabean cake & 24.00 & 24.00 & 24.00 & 24.00 & 24.00 \\
\hline Brewers dried grain & 6.25 & 6.25 & 6.25 & 6.25 & 6.25 \\
\hline Rice offal & 22.00 & 22.00 & 22.00 & 22.00 & 22.00 \\
\hline Fish meal & 3.50 & 3.50 & 3.50 & 3.50 & 3.50 \\
\hline Bone ash & 3.00 & 3.00 & 3.00 & 3.00 & 3.00 \\
\hline Methionine & 0.30 & 0.30 & 0.30 & 0.30 & 0.30 \\
\hline Lysine & 0.20 & 0.20 & 0.20 & 0.20 & 0.20 \\
\hline Vitamin/Mineral premix* & 0.25 & 0.25 & 0.25 & 0.25 & 0.25 \\
\hline Table salt & 0.50 & 0.50 & 0.50 & 0.50 & 0.50 \\
\hline Total & 100 & 100 & 100 & 100 & 100 \\
\hline \multicolumn{6}{|l|}{ Calculated Nutrients } \\
\hline Crude Protein \% & 19.51 & 19.23 & 18.94 & 18.65 & 18.36 \\
\hline Metabolisable energy $\mathrm{kcal} / \mathrm{kg}$ & 2568.17 & 2548.12 & 2528.07 & 2508.02 & 2487.97 \\
\hline Fibre $\%$ & 12.76 & 13.18 & 13.6 & 14.02 & 14.43 \\
\hline Ether extract \% & 2.39 & 2.34 & 2.29 & 2.24 & 2.19 \\
\hline Lysine \% & 1.09 & 1.08 & 1.06 & 1.05 & 1.04 \\
\hline Methionine \% & 0.64 & 0.63 & 0.62 & 0.61 & 0.60 \\
\hline
\end{tabular}

MFRM: Mango Fruit Reject Meal

Vitamin/Mineral premix*:Animal care vitamin/mineral premix included at $0.25 \%$, translating to 24000 iu vitamin A, 6000 iu vitamin B, $60 \mathrm{mg}$ vitamin $E, 5 \mathrm{mg}$ vitamin K3, $2 \mathrm{mg}$ Folic acid, $80 \mathrm{mg}$ niacin, $4 \mathrm{mg}$ vitamin BI, $10 \mathrm{mg}$ Vitamin B2, $7 \mathrm{mg}$ vitamin B6, 0.04mg Vitamin B12, $0.16 \mathrm{mg}$ biotin and $250 \mathrm{mg}$ antioxidant per $\mathrm{kg}$ diet. The minerals values per $\mathrm{kg}$ diet were: cobalt $0.5 \mathrm{mg}$, copper $16 \mathrm{mg}$, selenium $0.5 \mathrm{mg}$, iodine $24 \mathrm{mg}$, iron $80 \mathrm{mg}$, manganese $140 \mathrm{mg}$, zinc $120 \mathrm{mg}$ and chloride $400 \mathrm{mg}$. 


\section{Experimental animals and design}

A total of twenty (20) weaned rabbits of mixed breed and sex, aged approximately five weeks with a mean live weight of $454.21 \pm 20.62 \mathrm{~g}$ were purchased from the Rabbitry Section, Livestock unit, Teaching and Research Farm, University of Agriculture Makurdi, Benue State, Nigeria and used for the study. The animals were randomly allocated to five dietary treatment groups of four rabbits per group, and each rabbit formed a replicate in a completely randomized design with the following model:

$$
\underset{j \mathrm{~K}}{\mathrm{X}}+\underset{\mathrm{a}}{\mathrm{a}} \quad \mathrm{j} \quad \mathrm{jk}
$$

where

$\mathrm{X}_{\mathrm{jk}}=$ an observation in which $\mathrm{k}$ is the replicate of treatment $\mathrm{j}$,

i $=$ mean of the observed values,

á =effect of the treatment and

$\mathrm{j}$

$\mathrm{a}_{\mathrm{jk}}=$ experimental error

\section{Housing and management of experimental animals}

The rabbits were housed in hutches with a dimension of $60 \mathrm{~cm} \times 60 \mathrm{~cm} \times 60 \mathrm{~cm}$ inside a wall less structure. The initial weights of the animals were taken, balanced and the rabbits were randomly allocated to the hutches. Diets were served daily from bulk measured weekly and cool portable water served ad-libitum throughout the feeding trial which lasted for 70days. Necessary management practices $^{21}$ were duly observed.

\section{Data collection and analysis}

Carcass yield: Prior to the termination of the experiment, three rabbits per treatment were fasted of feed for $18 \mathrm{hrs}$ and their weights recorded. After that, the animals were bled and the carcass evaluated as described by Aduku ${ }^{8}$ ). Carcass was separated into the cuts namely hind limb, forelimb, back and loin, racks and neck. Offal's separated included the head, tail and feet. Each of the cuts were weighted and recorded. Fur weight was determined as the difference between empty weight and singed weight.

Internal organs: Each of the animals used in the carcass evaluation, had its internal organs examined as well. Internal organs namely; liver, kidney, spleen, heart, lungs and gall bladder were separated and weighed using an electronic scale.

Gastro-intestinal tract (GIT): Gastro-intestinal tracts of sacrificed animals were evaluated by measuring both the length and weight of each of the GIT parts: Small intestine, large intestine, stomach and caecum.

All data for evaluation of carcass and internal organs except fasted weights were converted to percentages of fasted weight. Data on GIT parts' lengths were converted to percentage GIT length. These data whose percentages were below 30 or above 70 were transformed using arcsine transformation as described by Little and Hills (1977) before analysis of variance was done. Apart from transformation, data were tested for normality before analysis of variance was done on those that were normally distributed, using SPSS. ${ }^{22}$

Data analysis: Data generated were subjected to analysis of variance using statistical software, ${ }^{22}$ which was configured to automatically separate means that were significantly different, using its Duncan multiple range taste.

\section{Results and discussion}

\section{Carcass and fur yield}

The results of fasted weight and carcass cuts; namely hand limb, fore limb, back and loin, racks, head, feet and tail; the last three been offal's were presented in Table 2. Also presented in Table 2 was the fur yield, which was significantly lower $(\mathrm{P}<0.05)$ at $0 \%$ MFRM. Apart from fasted and head weights; the former being significantly heavier, while the latter significantly lower at 20\% MFRM, there was no significant difference $(\mathrm{P}>0.05)$ among the treatment groups for the rest of the carcass parameters. Fasted weight variation among treatment groups was largely a function of growth performance since other processing procedures were applied across treatment groups. The fasted weight is majorly determined by growth factors. Growth parameters such as weight gain, feed intake, FCR, protein intake and protein conversion efficiency were similar to control when the same diets were served rabbits and the same management procedures were followed, with a tendency of being significantly higher $(\mathrm{P}<0.05)$ at $20 \%$ MFRM for final weight; quantitatively higher. ${ }^{12}$ Relative weights of carcass cuts were not significantly affected ( $>>0.05)$. This showed that the diets did not exert negative effects on lean meat tissue accretion. Diets may not have effect on the whole weight of an animal but still affect the distribution of meat and offal in the carcass. Having similar dressed percent across treatment groups meant that none of the diets occasioned excessive deposit of internal fat (an offal) or GIT weight at the expense of lean meat tissue. Hind and fore limbs are meat parts and their similarity showed that the supported good carcass development across the treatment groups. This result agrees with the report of Orayaga et al. ${ }^{12}$ who reported $20 \%$ MFRM as being safe and more economical level in rabbit diets, when it was included from $5 \%$ to $20 \%$ and the growth performance was evaluated. Though the mango fruit reject used in this experiment had low crude protein content $(3.24$ $\%$ ) compared to maize with $8.9 \%$ crude protein, ${ }^{18}$ and according to report ${ }^{23}$ mango pulp and peel ${ }^{24}$ are said to be low in crude protein ranging from 2.70 to $6 \%$ and 4.70 to $9 \%$, respectively, all the diets had the protein level optimum for grower rabbits, which ensured their similar carcass yield (dressed percent). The fasted weight reported here was higher than 1154.00 to $1240.00 \mathrm{~g}$ reported by Yakubu et al. ${ }^{10}$ whose dressed percentage (39.31 to $47.91 \%$ ) was equally lower compared with this report (51.93 to $56.32 \%$ ). Dressed percent of rabbits; 49.04 to $55.23 \%$, reported by Orayaga et al., ${ }^{6}$ when rabbits were fed different sources of groundnut meals, was similar to this finding. Non-significant difference among treatment groups on major meat cuts namely hind limb, fore limb, loin and back means meat yield was not compromised at the expense of any of the offal's nor fur yield due to dietary effect. Non-significant difference in dressed percent implies that there was no disproportionate growth occasioned by the diets. Dressed percent will be adversely affected by diets if some diets cause the development of offal's at the expense of lean meat accretion or the presence of anti-nutritional factors or disease condition hinder proper growth and development of the animal. 
Fur yield, being significantly lower at $0 \%$ MFRM means fur yield was actually affected by MFRM positively. This is because while the control had $7.71 \%$ fur yield, the rest of the treatment groups were $10.16 \%$ to $11.56 \%$, increasing steadily as the level of MFRM increased in the diets. This result was lower than $10.64 \%$ to $16.67 \%$ fur yield reported by Shittu et al. ${ }^{25}$ However, a similar trend was observed with the diets having mango seed kernel meals; they had better fur yield quantitatively than the control. It means the test material (MFRM) contributed to better growth of fur. Fur or hair or wool growth can be affected by diet. Mango fruit pulp is used as a hair nourishing ingredient in humans. ${ }^{26}$ This is a plus to fibre industries because though rabbits are produced in many countries for meat, fur is still important to many producers for fibre industries.

Internal organs relative weights were not significantly affected (Table 3 ) among the dietary treatments groups. Organ relative weights were generally below 0.40 to $0.44 \%$ hearts and 4.47 to $5.47 \%$ liver, reported by Shittu et al. ${ }^{24}$ when rabbits were fed diets containing mango seed kernel. Berardini et al. ${ }^{27}$ implicated anti-nutritional factors as been responsible for disproportionate enlargement of organs such as gall and liver, indicating improper health condition. Abnormal blood circulation occasioned by dietary factors would cause variation in the size of the heart. Non-significant difference among the treatment groups for heart (percent live weight) indicated a normal blood circulation among all the dietary groups.

Mango pulp has a good number of acids such as malic, citric, ascorbic and tartaric acids which disintegrate upon ripening; if the ripening undergoes a normal process. Mango fruit rejects do not necessary undergo a normal ripening since the could be gotten at Table 2 Effect of MFRM on carcass and fur yield of rabbits. any level of the fruits' development as long as they become unfit for human use and may retain much of the acids, including the anti-nutritional factors of the peel such as tannic acid. These were implicated for depressed performance in chicken. ${ }^{2}$ More so, Aduku et al. ${ }^{8}$ remarked that factors like age, diet and body weight affect organ relative weights. The fact that there was no disproportionate enlargement of the internal organs beyond normal both against control and past reports showed that the rabbits tolerated the test ingredients and were not harmed at this level of inclusions of the test ingredients. It also means MFRM did not introduce poison in the diets and the anti-nutritional levels were tolerable to the rabbits. Orayaga et al. ${ }^{1}$ had reported the presence of anti-nutritional factors such as tannin in MFRM which affected chickens; but no adverse effect on rabbits. ${ }^{12}$

\section{Gastro-intestinal Tract (GIT) Morphometry}

Gastro-intestinal tract morphometry results were presented in Table 4. Apart from Caeca length which varied without pattern, other GIT components (weight or length) were not significantly affected $(\mathrm{P}>0.05)$. Relative weights of GIT and its components were not significantly affected $(\mathrm{P}>0.05)$ and there was no significant difference in the relative lengths of small intestine and large intestine. This implies that the diets did not place extra load on these GIT components to necessitate extra development of the organs to cope; as in the case when there is high fibre than necessary in monogastric diets.

Caecum length was significantly different $(\mathrm{p}<0.05)$ among treatment groups without pattern. The caecum is the site for water reabsorption and fermentation of digestible fibre for caecotrope production. The non-patterned variation is not clearly understood.

\begin{tabular}{|c|c|c|c|c|c|c|c|}
\hline \multirow{3}{*}{ Weight of part/parameter (\%) } & \multicolumn{5}{|c|}{ Experimental diets } & \multirow{3}{*}{ SEM } & \multirow[t]{3}{*}{ LS } \\
\hline & $0 \%$ & $5 \%$ & $10 \%$ & $15 \%$ & $20 \%$ & & \\
\hline & MFRM & MFRM & MFRM & MFRM & MFRM & & \\
\hline Final Body Weight (g) & $1508.33^{\mathrm{b}}$ & $1558.33^{\mathrm{b}}$ & $1591.67^{\mathrm{ab}}$ & $1475.00^{\mathrm{b}}$ & $1758.33^{\mathrm{a}}$ & 54.9 & $\mathrm{~S}$ \\
\hline Bled & 92.81 & 94.55 & 94.25 & 94.83 & 94.66 & 0.91 & NS \\
\hline Eviscerated & 73.92 & 74.38 & 74.34 & 72.42 & 72.55 & 1.53 & NS \\
\hline Singed & 66.21 & 64.22 & 64.11 & 61.95 & 61.03 & 1.82 & NS \\
\hline Fur & $7.71^{\mathrm{b}}$ & $10.16^{\mathrm{a}}$ & $10.23^{\mathrm{a}}$ & $10.47^{\mathrm{a}}$ & $11.52^{\mathrm{a}}$ & 1.99 & S \\
\hline Dressed percent & 56.32 & 53.88 & 54.62 & 51.93 & 52.39 & 1.84 & NS \\
\hline Fore limb & 9.22 & 8.95 & 8.72 & 9.21 & 8.27 & 0.54 & NS \\
\hline Hind limb & 15.42 & 13.79 & 15.18 & 14.62 & 14.06 & 0.64 & NS \\
\hline Back/racks & 8 & 8.49 & 8.03 & 7.93 & 7.73 & 0.53 & NS \\
\hline Neck & 2.31 & 2.37 & 2.8 & 2.85 & 2.49 & 0.15 & NS \\
\hline Loin & 17.06 & 17.97 & 17.8 & 16.87 & 20.46 & 0.95 & NS \\
\hline Feet & 1.79 & 1.88 & 1.83 & 2.03 & 1.71 & 0.14 & NS \\
\hline Head & $7.73^{\mathrm{a}}$ & $7.89^{\mathrm{a}}$ & $7.24^{\mathrm{ab}}$ & $7.57^{\mathrm{a}}$ & $6.45^{\mathrm{b}}$ & 0.26 & $\mathrm{~S}$ \\
\hline Tail & 0.38 & 0.56 & 0.43 & 0.42 & 0.48 & 0.04 & NS \\
\hline
\end{tabular}

MFRM, mango fruit reject meal

SEM, standard error of mean,

LS, level of significance $(P<0.05)$

NS, no significant difference $(P>0.05)$ 
Table 3 Effect of MFRM on internal organ characteristics of rabbits

\begin{tabular}{|c|c|c|c|c|c|c|c|}
\hline \multirow{3}{*}{ Parameter (\%) } & \multicolumn{5}{|c|}{ Experimental diets } & \multirow{3}{*}{ SEM } & \multirow{3}{*}{ LS } \\
\hline & $0 \%$ & $5 \%$ & $10 \%$ & $15 \%$ & $20 \%$ & & \\
\hline & MFRM & MFRM & MFRM & MFRM & MFRM & & \\
\hline Final body Weight (g) & $1508.33^{b}$ & $1558.33^{\mathrm{b}}$ & $1591.67^{\mathrm{ab}}$ & $1475.00^{\mathrm{b}}$ & $1758.33^{\mathrm{a}}$ & 54.94 & $\mathrm{~S}$ \\
\hline Heart & 0.24 & 0.30 & 0.24 & 0.34 & 0.22 & 0.03 & NS \\
\hline Kidney & 0.61 & 0.61 & 0.67 & 0.70 & 0.7 & 0.07 & NS \\
\hline Stomach & 1.02 & 1.37 & 1.29 & 1.29 & 1.36 & 0.15 & NS \\
\hline Fat & 0.56 & 1.40 & 1.60 & 1.38 & 2.23 & 0.55 & NS \\
\hline Liver & 2.31 & 2.40 & 2.46 & 2.70 & 2.71 & 0.12 & NS \\
\hline Gall & 0.07 & 0.07 & 0.04 & 0.09 & 0.04 & 0.03 & NS \\
\hline Spleen & 0.07 & 0.05 & 0.04 & 0.04 & 0.04 & 0.00 & NS \\
\hline Lungs & 0.46 & 0.52 & 0.50 & 0.56 & 0.51 & 0.27 & NS \\
\hline
\end{tabular}

MFRM, mango fruit reject meal

SEM, standard error of mean,

NS, no significant difference $(P>0.05)$

$\mathrm{S}$, significant difference $(\mathrm{P}<0.05)$

LS, level of significance $(P<0.05)$

Table 4 Effect of MFRM on GIT morphometry of rabbits

\begin{tabular}{|c|c|c|c|c|c|c|c|}
\hline \multirow{3}{*}{ Parameter (\%) } & \multicolumn{5}{|c|}{ Experimental diets } & \multirow{3}{*}{ SEM } & \multirow{3}{*}{$\mathbf{L S}$} \\
\hline & \multirow{2}{*}{$\begin{array}{l}\text { 0\% } \\
\text { MFRM }\end{array}$} & \multirow{2}{*}{$\begin{array}{l}\mathbf{5 \%} \\
\text { MFRM }\end{array}$} & \multirow{2}{*}{$\begin{array}{l}10 \% \\
\text { MFRM }\end{array}$} & \multirow{2}{*}{$\begin{array}{l}15 \% \\
\text { MFRM }\end{array}$} & \multirow{2}{*}{$\begin{array}{l}20 \% \\
\text { MFRM }\end{array}$} & & \\
\hline & & & & & & & \\
\hline Final body Weight (g) & $1508.33^{b}$ & $1558.33^{b}$ & $1591.67^{\mathrm{ab}}$ & $1475.00^{\mathrm{b}}$ & $1758.33^{\mathrm{a}}$ & 54.94 & $\mathrm{~S}$ \\
\hline GIT (\%final weight) & 2.92 & 3.05 & 3.04 & 3.38 & 3.30 & 0.18 & NS \\
\hline Small intestine (\%final weight) & 1.74 & 2.06 & 1.84 & 1.74 & 1.78 & 0.22 & NS \\
\hline Large intestine (\%final weight) & 0.85 & 0.95 & 1.06 & 1.28 & 1.11 & 0.12 & NS \\
\hline Caeca (\%final weight) & 1.76 & 1.75 & 1.34 & 1.42 & 1.18 & 0.18 & NS \\
\hline GIT length $(\mathrm{cm})$ & 450.5 & 420.43 & 457.6 & 417.67 & 471.67 & 15.94 & NS \\
\hline Small intestine (\%GIT) & 69.31 & 67.31 & 67.91 & 62.32 & 66.46 & 1.86 & NS \\
\hline Large intestine $(\% \mathrm{GIT})$ & 15.4 & 16.09 & 14.84 & 14.99 & 14.08 & 0.62 & NS \\
\hline Caeca $(\%$ GIT $)$ & $10.33^{\mathrm{ab}}$ & $12.14^{\mathrm{a}}$ & $9.37^{\mathrm{b}}$ & $12.02^{\mathrm{a}}$ & $10.26^{\mathrm{ab}}$ & 0.60 & $\mathrm{~S}$ \\
\hline
\end{tabular}

MFRM, mango fruit reject meal

SEM, standard error of mean

LS, level of significance $(P<0.05)$

NS, no significant difference $(P>0.05)$

$\mathrm{S}$, dignificant $(\mathrm{P}<0.05)$

GIT, gastro-intestinal tract

\section{Conclusion}

\section{Conclusion and application}

Mango fruit reject meal in rabbit diets supported performance as good as maize, and have surpassed maize with respect to fasted weight. It is therefore concluded that:

i. MFRM is a good feed resource in rabbit nutrition.

ii. MFRM feeding to rabbits is economical and should be included in rabbit diets at $20 \%$ level.

iii. It is recommended that further investigations should be carried out at higher levels (above 20\%) of MFRM in rabbit diets and carcass evaluated.

\section{Acknowledgements}

The College of Animal Science, Teaching and Research Farm is sincerely acknowledged for providing the necessary facilities for the conduct of the research.

\section{Conflict of interest}

The author declares no conflict of interest. 


\section{References}

1. Orayaga KT. The Nutritive Value of Composite Mango (Mangifera Indica) Fruit Reject As a Feed Resource in Broiler Chickens Diets. Ph.D Thesis submitted to the Department of Animal Nutrition, Makurdi, Nigeria: University of Agriculture; 2016. 206 p

2. Orayaga KT, Oluremi OIA, Tuleun CD, et al. The feed value of composite mango (Mangifera indica) fruit reject meal in the finisher broiler chickens nutrition. African Journal of Food Science and Technology. 2015;6(6):177-184

3. Orayaga, KT, Oluremi OIA, Adenkola AY. Effect of water soaking of sweet orange (Citrus sinensis) fruit peels on haematology, carcass yield and internal organs of finisher broiler chickens. Journal of Animal Health and Production. 2016;4(3):65-71.

4. Orayaga KT, Goholshak PM. Comparative evaluation of different sources of groundnut meals on digestibility, growth performance and economics of production of growing rabbits. Nigerian Journal of Animal Production. 2014;41(1):272-283.

5. Orayaga KT, Anugwa FOI. The proximate composition of boerhavia diffusa dried leaves and its effect on the growth performance of weaned rabbits. In: Abdullah AR, et al, editors. Proceedings, 39 ${ }^{\text {th }}$ Conference, Nigerian Society of Animal Production, 16-19 March, 2014. IlishanRemo, Ogun State, Nigeria: Babcock University; 2014. p. 297-300.

6. Orayaga KT, Ayoade JA, Dosa JJ. Effects of three sources of groundnut (Arachis hypogea) meal on carcass yield, internal organs and meat quality of rabbits. Journal of Animal Production Advances. 2016;6(9):991-998.

7. Abdu SB, BakoH, Hassan MR, et al. Effects of charcoal inclusion on the performance of growing rabbits fed Acacia (Acacia nolitica) pod meal based diets. Nigerian Journal of Animal Science. 2011;13:133-141.

8. Aduku AO, Olukosi J. Rabbit management in the tropics. Living Book Series Abuja FCT; 1990. p. 35-68.

9. Odeyinka SM, Oyedele OJ, Odedire JA. Reproductive performance of rabbits fed Moringa oleifera as a replacement for Centrosema pubsescens. $9^{\text {th }}$ World Rabbit Congress. June, 10 $0^{\text {th }}-13^{\text {th }}$, Verona-Italy; 2008.

10. Yakubu B, Wafar RJ. Effects of processing methods of leptadenia hastata on growth performance, nutrient digestibility and carcass characteristics of weaner rabbits. Journal of Agriculture and Veterinary Science. 2014;7(1):53-58.

11. Saleh N, Bello KM, Muhammad AS. Effects of Replacing maize with mango seed kernel meal on performance, carcass characteristics and economic of production of weaner rabbits. International Journal of Geology Agriculture and Environmental Sciences. 2015;3(2):29-32.

12. Orayaga KT. The effect of composite mango (Mangifera indica) Fruit reject meal on growth performance, digestibility and economics of production of rabbits. Nigerian Journal of Animal Science. 2016;18(1):65-75.
13. USDA. National Nutrient Database for Standard Reference. SR-23, Fruit Reports-09, Mango, Raw; 2010. 449 p.

14. FAO. Top producers of mangoes, mangosteens and guavas. 2014.

15. Sruamsiri S, Silman P. Nutritive value and nutrient digestibility of ensiled mango by-products. Maejo International Journal of Science and Technology. 2009;3(03):371-378.

16. Porter L. Nutritional data for dried mango. Official partner of the livingstrong foundation; 2011.

17. Roa DS, Ravi A, Yedukondalu R. Inclusion of dried mango peels in finisher rations of pigs on their performance. Indian Journal of Animal Nutrition. 2003;20(1):120-123.

18. Aduku AO. Animal Nutrition in the Tropics: Feeds and Feeding, Pasture Management, Monogastric and Ruminant Nutrition. Davcon Computers \& Business Bureau, Zaria, Nigeria; 2004. p. 5-143.

19. TAC. Makurdi weather elements records. Makurdi Metereological Station Nigerian Air force, Makurdi, Nigeria: Tactical Air Command; 2009.

20. AOAC. Official Methods of Analysis. Association of Official Analytical Chemists. 16th ed. Richard Virginia, USA: William Tryd Press; 2000. p. $17-34$.

21. Fielding D. Rabbits. Centre for Tropical Veterinary Medicine, University of Edinburgh in cooperation with the technical center for Agricultural and Rural cooperation, the Netherlands. London: Mc Millian Press Ltd; 1991. p. $42-47$.

22. SPSS. Statistical package for Social Sciences. Procedures and facilities for release. 6.0 Users' Mannual. New York, USA: McGraw-Hill Book Co; 1999.

23. Palma Castillo OR, Hurtado EA. Productive behaviour of rabbit during the fattening growth period, fed with mango as partial substitution of the commercial balanced food. Revista Cientifica Udo Agricola. 2009;9(4):968-971.

24. Rego MMT, Neiva JNM, Rego AC, et al. Intake, nutrients digestibility and nitrogen balance of elephant grass silages with mango by-product addition. Revista Brasilia de Zootecnia. 2010;39(1):74-80.

25. Shittu MD, Olabanji RO, Ojebiyi OO, et al. Nutritional evaluation of processed mango (Mangifera indica-kent) seed kernel meal as replacement for maize in the diet of growing crossbred rabbits. Online Journal of Animal and Feed Research. 2013;3(5):210-215.

26. Tadimalla RT. Twenty (20) Amazing Benefits Of Mangoes For Skin, Hair, And Health. Stylecraze; 2017.

27. Berardini N, Fezer R, Conrad J, et al. Screening of mango (Mangifera indica L.) cultivars for their contents of flavonol and xanthone C-glycosides, anthocyanins, and pectin. J Agric Food Chem. 2005;53(5):1563-1570. 